\title{
ІДЕАЛЬНИЙ ОБРАЗ УКРАЇНЦІВ У СПРИЙНЯТТІ РІЗНИХ СОЦІАЛЬНО-ВІКОВИХ ГРУП МОВЦІВ
}

Ляшук Н. В. Ідеальний образ українців у сприйнятті різних соціально-вікових груп мовців.

У статті аналізуються результати соціолінгвістичного експерименту, мета якого дослідити ідеальний образ українців у сприйнятті різних соціальних груп. Соціолінгвістичний аспект дослідження дає можливість вивчити специфіку мовного портретування українців різними віковими групами, простежити основні відмінності та подібності у створених варіантах автостереотипу.

Ключові слова: ідеальний образ, автостереотип, соціолінгвістичний експеримент, мовна свідомість, респондент.

Ляшук Н. В. Идеальный образ украинцев в восприятии разных социальновозрастных групп.

В предлагаемой статье анализируются результаты социолингвистического эксперимента, цель которого изучить идеальный образ украинцев в восприятии разных социальных групп. Социолингвистический аспект исследования позволяет изучить специфику языкового портретирования украинцев разными возрастными группами, проследить отличия и сходства в образованных вариантах автостереотипа.

Ключевые слова: идеальный образ, автостереотип, социолингвистический експеримент, языковое сознание, реципиент.

Liashuk N. V. Ideal type of the Ukrainians at the apprehension of different social group.

The article deals with the analysis of the results of the sociolinguistic experiment which aim is to reveal the ideal Ukrainians type at the apprehension of different social group. The sociolinguistic aspect of the research gives the possibility to study the peculiarity of the linguistic Ukrainians portrait at the apprehension of different age group, to retrace the main differences and resemblences among the autostereotype variants.

Key words: ideal type, autostereotype, sociolinguistic experiment, linguistic consciousness, recipient.

Зміна загальнонаукової парадигми за останні роки 3 позицій міждисциплінарної взаємодії відкриває великі можливості дослідження мови як людського фактору. У цьому контексті соціолінгвістика зосереджена на вивченні мови, що функціонує в конкретному середовищі, засвідчує нові перспективи співробітництва з соціологією (С. К. Богдан [1], Л. Т. Масенко [6], Г. М. Залізняк [6], К. І. Мізін [9], О. І. Горошко [3], Л. О. Ставицька [11]), етнологією (В. В. Жайворонок [5], В. А. Маслова [8], І. О. Голубовська [2], Н. О. Данилюк [4]) та психологією (Л. В. Засєкіна, С. В. Засєкін [7], В. П. Мусієнко [10]). Усе частіше лінгвісти звертаються до проблеми мовного самовияву людини, сучасних соціокомунікативних процесів, когнітивних універсалій.

Для перевірки гіпотез та розкриття концептуальних положень здійснено соціолінгвістичний експеримент методом анкетування. У 
сучасній науці експериментальна методика визнана досить ефективною й перспективною (Л. Т. Масенко, Г. М. Залізняк, К. І. Мізін, О. І. Горошко та ін.), оскільки проведення соціолінгвістичного експерименту дозволяє отримати кількісні та якісні показники щодо функціонування в мовній свідомості певного явища; статистичні дані дають змогу визначити, який образ постає стереотипним для певної соціальної групи. Методика психолінгвістичного аналізу результатів уможливлює дослідження національно-мовного наповнення слів-стимулів, встановлення можливих відмінностей у мовній свідомості носіїв певного соціолекту.

Для проведення цілеспрямованого соціолінгвістичного експерименту розроблено анкету, де респонденти фіксували уявлення про зовнішні дані українки та українця. Респондентам пропонувалося описати вказані в анкеті соматизми як ідеальні для української дівчини та хлопця, а також не бажані для ідеалу риси. Формуючи комплекс соматизмів, ми намагалися створити деталізовану характеристику зовнішності українців, щоб визначити основні риси зовнішності, що вказують на специфіку українського етносу.

Експеримент проводився серед представників міста Луцька та Волинської області. Вибіркою охоплено три основні соціальні групи: школярі $(25,5 \%)$, студенти $(40,7 \%)$, респонденти віком від 25 до 55 років $(33,8 \%)$. В експерименті брали участь школярі 10-х класів ЗОШ №1 міста Луцька (100 респондентів, 15-16 років), студенти ВНУ імені Лесі Українки різних факультетів, студенти ЛНТУ різних факультетів (160 респондентів, 18-23 років) та респонденти віком від 25 до 55 років (103 респонденти) представники різних професій (переважно вчителі, бібліотекарі, працівники державної служби, економісти).

Зібраний та підрахований фактичний матеріал дав змогу створити ідеальні образи українки та українця в уявленні представлених трьох вікових груп і провести порівняльний аналіз. Обробка емпіричних даних починалася з одномірного аналізу - підрахунку абсолютних величин, їх процентного розподілу, визначення середнього арифметичного і стандартного відхилень. Найчастотніші відповіді у процентному співвідношенні вказані в таблиці.

Порівняльний аналіз показав, що ідеальний образ української дівчини досить стереотипний в уявленні всіх представлених вікових категорій. Це підтверджують найчастотніші реакції, дані різними групами реципієнтів: брови - тонкі, чорні, очі - голубi / блакитні, карі, щоки рум'яні, пухкі, зуби - білі, рівні, вуха - маленькі, шия - тонка, довга, плечі - вузькі, талія - тонка, ноги - довгі - їх можна вважати найстійкішими складовими автостереотипу.

Слово-стимул голова спонукав до подібних частотних реакцій у школярів та старшого покоління, що вказували на форму голови (овальна), а також інтелектуальний рівень людини (розумна). У студентів домінують відповіді лише зі значенням форми голови: овальна і розумна. 
Ідеальні риси української дівчини

\begin{tabular}{|c|c|c|c|c|c|c|}
\hline Соматизм & $\begin{array}{c}\text { Відповіді } \\
\text { школярів } \\
\text { (15-16 років) }\end{array}$ & $\%$ & $\begin{array}{c}\text { Відповіді } \\
\text { студентів } \\
\text { (18-23 років) }\end{array}$ & $\%$ & \begin{tabular}{|c|} 
Відповіді \\
респондентів \\
віком 25-55 років
\end{tabular} & $\%$ \\
\hline \multirow{2}{*}{ Голова } & овальна & 51,0 & овальна & 37,5 & овальна & 34,0 \\
\hline & розумна & 17,0 & кругла & 20,6 & розумна & 28,2 \\
\hline Обличчя & овальне & 44,0 & овальне & 29,4 & овальне & 34,0 \\
\hline \multirow{2}{*}{ Волосся } & довге & 36,0 & довге & 28,8 & довге & 31,1 \\
\hline & чорне & 14,0 & русяве & 16,3 & русяве & 18,4 \\
\hline \multirow{2}{*}{ Брови } & тоненькі & 46,0 & чорні & 30,6 & чорні & 40,8 \\
\hline & чорні & 21,0 & тонкі & 24,4 & тонкі & 24,3 \\
\hline \multirow{2}{*}{ Очі } & голубі / блакитні & 28,0 & карі & 30,6 & карі & 37,9 \\
\hline & карі & 21,0 & голубі/блакитні & 30,0 & голубі/блакитні & 21,4 \\
\hline Щоки & рум'яні & 44,0 & рум'яні & 28,8 & рум'яні & 36,9 \\
\hline \multirow{2}{*}{ Вуста } & пухкі & 27,0 & пухкі & 28,1 & пухкі & 32,0 \\
\hline & рожеві & 21,0 & повні & 16,9 & червоні & 21,4 \\
\hline \multirow{2}{*}{ Зуби } & білі & 65,0 & білі & 48,8 & білі & 55,3 \\
\hline & рівні & 34,0 & рівні & 43,8 & рівні & 29,1 \\
\hline Byха & маленькі & 45,0 & маленькі & 55,6 & маленькі & 54,4 \\
\hline Hic & рівний & 32,0 & маленький & 32,5 & маленький & 35,0 \\
\hline \multirow{2}{*}{ Шия } & тонка & 41,0 & тонка & 40,0 & довга & 37,9 \\
\hline & довга & 39,0 & довга & 30,0 & тонка & 30,1 \\
\hline \multirow{2}{*}{ Шкіра } & смугла & 26,0 & смугла & 23,1 & світла & 24,3 \\
\hline & засмагла & 20,0 & засмагла & 17,5 & біла & 23,3 \\
\hline Плечі & вузькі & 59,0 & вузькі & 65,6 & вузькі & 57,3 \\
\hline \multirow{2}{*}{ Руки } & тонкі & 26,0 & ніжні & 28,8 & ніжні & 28,2 \\
\hline & ніжні & 19,0 & середньої довжини & 23,8 & працьовиті & 16,5 \\
\hline Талія & тонка & 47,0 & тонка & 40,6 & тонка & 38,8 \\
\hline Ноги & довгі & 45,0 & довгі & 41,9 & довгі & 47,6 \\
\hline \multirow{2}{*}{ Постава } & рівна & 46,0 & струнка & 43,1 & струнка & 55,3 \\
\hline & струнка & 34,0 & рівна & 26,9 & рівна & 22,3 \\
\hline 3ріст & середній & 58,0 & середній & 51,9 & середній & 46,6 \\
\hline \multirow{2}{*}{ Лоб } & маленький & 45,0 & високий & 25,6 & високий & 35,0 \\
\hline & високий & 21,0 & малий & 25,6 & середній & 27,2 \\
\hline Pot & середній & 50,0 & середній & 36,3 & малий & 33,0 \\
\hline
\end{tabular}

Протилежними за значенням виявилися найчастотніші відповіді на стимул шкіра. Школярі та студенти ідеальною в української дівчини вважають смуглу та засмаглу шкіру, а більшість респондентів старшого покоління відзначають красивою світлу та білу шкіру. Таку полярність відповідей можна пояснювати впливом інших культур та зміною естетичних ідеалів сучасної молоді. На противагу молоді старше покоління дотримується і відтворює в мові цінності, закладені українським народом ще у фольклорі. 
У респондентів старшої вікової групи соматизм руки (в української дівчини) викликав такі типові реакції - ніжні, працьовиті. Школярі подають наступні якісні характеристики - тонкі, ніжні, студенти - ніжні, середньої довжини. Очевидно, ідеальний образ рук у сучасної молоді не асоціюється з працездатністю.

Як свідчить порівняння стереотипних реакцій, респонденти трьох груп віддають перевагу різному кольору волосся в української дівчини: школярі - чорне; студенти - русяве; дорослі - русяве, або формі носа: школярі - рівний; студенти - маленький; дорослі - маленький. Така незначна відмінність вказує на вияв у стереотипах соціальної специфіки.

Образ українського хлопця виявився не менш стереотипним, ніж образ української дівчини.

Таблиця 2

Ідеальні риси українського хлопця

\begin{tabular}{|c|c|c|c|c|c|c|}
\hline Соматизм & $\begin{array}{l}\text { Відповіді } \\
\text { школярів }\end{array}$ & $\%$ & Відповіді студентів & $\%$ & $\begin{array}{c}\text { Відповіді респондентів } \\
\text { віком 25-55 років }\end{array}$ & $\%$ \\
\hline Голова & овальна & 55,0 & овальна & 36,3 & овальна & 30,1 \\
\hline Обличчя & овальне & 42,0 & овальне & 36,3 & овальне & 34,0 \\
\hline \multirow[t]{2}{*}{ Волосся } & коротке & 35,0 & коротке & 37,5 & коротке & 26,2 \\
\hline & темне & 35,0 & чорне & 23,8 & темне & 24,3 \\
\hline \multirow[t]{2}{*}{ Брови } & чорні & 35,0 & чорні & 46,3 & чорні & 42,7 \\
\hline & густі & 29,0 & густі & 20,6 & темні & 17,5 \\
\hline \multirow[t]{2}{*}{ Очі } & карі & 43,0 & карі & 37,5 & карі & 43,7 \\
\hline & голубі & 23,0 & голубі & 31,9 & голубі & 19,4 \\
\hline Щоки & рум'яні & 43,0 & рум'яні & 23,1 & рум'яні & 33,0 \\
\hline \multirow[t]{2}{*}{ Вуста } & тонкі & 26,0 & пухкі & 20,6 & пухкі & 24,3 \\
\hline & середні & 26,0 & тонкі & 13,1 & червоні & 20,4 \\
\hline \multirow[t]{2}{*}{ Зуби } & білі & 75,0 & білі & 50,0 & білі & 59,2 \\
\hline & рівні & 23,0 & рівні & 40,6 & piвні & 27,2 \\
\hline \multirow[t]{2}{*}{ Byxa } & середні & 69,0 & середні & 40,6 & малі & 44,7 \\
\hline & малі & 24,0 & малі & 33,1 & середні & 41,7 \\
\hline \multirow[t]{2}{*}{ Hic } & рівний & 50,0 & прямий & 30,0 & прямий & 32,0 \\
\hline & прямий & 27,0 & рівний & 28,8 & малий & 17,5 \\
\hline Шия & довга & 36,0 & середнього розміру & 33,8 & довга & 32,0 \\
\hline \multirow[t]{2}{*}{ Шкіра } & світла & 34,0 & смугла & 31,9 & смугла & 32,0 \\
\hline & засмагла & 28,0 & засмагла & 21,9 & світла & 24,3 \\
\hline Плечі & широкі & 78,0 & широкі & 71,3 & широкі & 68,9 \\
\hline \multirow[t]{2}{*}{ Руки } & сильні & 39,0 & сильні & 26,3 & сильні & 27,2 \\
\hline & довгі & 25,0 & довгі & 23,1 & роботящі / робочі & 19,4 \\
\hline Талія & тонка & 26,0 & середніх розмірів & 19,4 & не охарактеризували & 30,1 \\
\hline Ноги & рівні & 34,0 & рівні & 30,6 & довгі & 29,1 \\
\hline Постава & рівна & 50,0 & струнка & 45,0 & струнка & 51,5 \\
\hline \multirow[t]{2}{*}{ Зріст } & Високий & 81,0 & високий & 50,0 & Високий & 61,2 \\
\hline & середній & 16,0 & 1 м. 80 см. & 25,0 & $185-190 \mathrm{~cm}$ & 29,1 \\
\hline Лоб & середній & 41,0 & середній & 32,5 & високий & 43,7 \\
\hline Pot & середній & 48,0 & середній & 46,3 & великий & 25,2 \\
\hline Byca & відсутні & 69,0 & відсутні & 89,4 & відсутні & 78,6 \\
\hline
\end{tabular}


Порівняння статистичних даних у змалюванні образу українця показало, що всі вікові групи одностайно визнали красивими такі риси: коротке, темне волосся, чорні брови, карі очі, білі, рівні зуби, рум'яні щоки, широкі плечі, сильні руки, рівні ноги, високий зріст, відсутність вусів. Саме ці риси можна вважати основними у виокремленні етнічного представника українців. Найважливіше те, що вони сформовані як ідеальні риси українця в мовній свідомості різних вікових груп і виражені тотожними мовними одиницями. Соціолінгвістичний експеримент демонструє, як реалізується колективний досвід, “колективне підсвідоме" через індивідуальну свідомість мовців.

Експеримент презентує певні відмінності в описі таких соматизмів: голова, обличчя, вуста, вуха, ніс, шия, шкіра, талія, лоб, рот. Зміну рейтингів однакових прикметникових описів спостерігаємо в оцінюванні вух (середні, малі), постави (струнка, рівна), лоба (середній, високий) i рота (середній, великий, малий). Тобто для опису вух, постави, лоба, рота, усі вікові категорії застосовують однакові прикметники, лише варіює відсоток респондентів. Відмінні за значенням лексеми фіксують для опису соматизмів: голова, обличчя, щоки, вуста, ніс, шия, шкіра, руки, талія, зріст. Майже всі частини тіла українського хлопця респонденти характеризують прикметниками, що виражають форму, розмір чи колір. Проте відповіді старшого покоління вказують не лише на якісні ознаки зовнішності, але й на внутрішнє наповнення: голова - овальна, розумна та руки - сильні, роботящі / робочі.

Те, що віковий ценз має вплив на уявлення ідеального образу, підтверджують різні характеристики талії українського хлопця. 3 віком простежується тенденція до відмови подавати ідеальні ознаки талії. Школярі ідеальною описують тонку та худу талію, студенти - середніх розмірів, спортивну, великий відсоток (30\%) респондентів старшого покоління вважають таку рису неважливою у створенні образу українського хлопця, а 21\% вказують неконкретні параметри - середнього розміру. Цей випадок демонструє суб'єктивний чинник в оцінюванні українців, можливо, асоціативно змінюється вектор оцінювання 3 конкретного національного образу на представників своєї вікової групи.

Для детального аналізу автостереотипу українців та можливості протиставлення експеримент також передбачає збір інформації про небажані для ідеалу риси української дівчини та хлопця.

Очевидно, що неідеальні образи українців виявилися теж досить стереотипними. Проте простежується більша узгодженість в уявленні неідеальних рис дівчини, ніж хлопця. Усі вікові групи однаково вважають, що небажаними для української дівчини є: коротке та руде волосся, малі та вузькі очі, тонкі вуста, криві та жовті зуби, клаповухі та великі вуха, широкі плечі, грубi руки, широка та товста талія, криві та короткі ноги, великий чи широкий рот. Для українського хлопця однозначно некрасивими 
визнали лише 5 ознак (коли у дівчини 10): довге волосся, жовті, криві зуби, клаповухі, великі вуха, вузькі плечі, короткі, криві ноги, наявність вусів. Можливо, цей факт пояснюється критичнішим ставленням мовців до дівочої краси, ніж до чоловічої, що й простежується на мовному рівні.

Варто зазначити, що типові асоціації для характеристики неідеального образу творяться переважно механічно, співвідносно до ідеальних асоціацій, структуруючи антонімічні пари. Наприклад: волосся довге коротке, ріст високий - низький, ніс рівний - кривий, вуха малі - великі, ноги довгі - короткі, шкіра світла - темна, плечі вузькі - широкі, руки ніжні- грубі, талія тонка - иирока, зуби рівні-криві.

Малочастотні та індивідуальні асоціації можна вважати периферійними ознаками зовнішності українців, проте вони становлять великий інтерес у компаративному дослідженні автостереотипів українки та українця, оскільки презентують мовне вираження оцінних еталонів різних соціальних та вікових груп. Д. І. Терехова, провівши асоціативний експеримент, зробила висновок, що “специфічні національні риси виявляються, як правило, в низькочастотних асоціаціях, що перебувають на периферії асоціативних полів” [12, с. 46].

Одиничні та малочастотні відповіді, як і високочастотні, становлять переважно синтагматичні асоціації (що разом зі стимулом утворюють підрядне словосполучення), які виражаються прикметниками зі значенням кольору, форми, розміру, наприклад: маленька голова, світле волосся, сині очі, округле обличчя, вузький лоб.

Соціолінгвістичний експеримент засвідчує, що велика частка респондентів, які описували зовнішність української дівчини та українського хлопця, застосовували не лише типові параметри (форма, колір, розмір), а й означення, які характеризують внутрішній стан людини, риси характеру, інтелект, функціональні можливості окремих частин тіла. Помічено, що вживання таких характеристик більш властиве старшій віковій групі (від 25 до 55 років) - зафіксовано 39 номінацій, у школярів - 30, у студентів 25. Наприклад, відповіді старшої вікової групи: голова - розумна (29), не розумна (25), порожня (6), “з діркою” (1); обличчя - добре (10), миле (10), зле (9), приємне (5), усміхнене (5), відкрите (3), сумне (3), веселе (2), неприємне (2), щире (1), ясне (1), насуплене (1); очі - злі (2), добрі (1), розумні (1), щуирі (1), порожні (1), сумні (1); вуста - солодкі (4), ніжні (1), чуттеві (1), вульгарні (1); шия - тендітна (7), ніжна (7); руки - ніжні (29), працьовиті (17), тендітні (14); ліниві (9), незграбні (1); постава горда (5), граційна (1), поважна (1); рот - мовчазний (1), ніжний (1), чуттєвий (1), з приємним запахом (1). Більша схильність дорослого покоління до застосування характеристик зі значенням внутрішнього стану людини, рис характеру та якості інтелекту підтверджується як кількісними, так і якісними показниками. 
Серед малочастотних та одиничних асоціацій трапляються такі, що описують не природні риси зовнішності, а набуті втручанням людини. Цікаво, що кожна вікова група фіксує свої критерії вдосконалення природної краси. Аналіз відповідей показав, що в описах старшої вікової групи переважають прикметники доглянутий / недоглянутий, чистий / брудний. У студентів та школярів 3'являються ще й такі вимоги до зовнішності, як фарбоване волосся, проколоті вуха, пірсинг, накачані ноги, плечі, руки. Цікаво, що студенти допускають варіант фарбованого волосся у хлопця, хоч це констатується, як неідеальна риса. Школярі красивими вважають вищипані брови в дівчини, вуха з пірсингом у хлопця та дівчини. Наведені приклади $є$ малочастотними, проте вони зорієнтовані на ціннісні пріоритети певної соціальної та вікової групи.

Майже усі типові й більшість індивідуальних відповідей виражаються прикметниками, проте в багатьох випадках для опису частин тіла використовується означення, у структурі якого $є$ іменник та прийменник, що деталізує образ. Різні вікові групи фіксують такі означення:

- школярі: обличчя зі змормками (1), брови гарної форми (1), вуха, сховані за волоссям (1), шкіра з прищами (3), руки з довгими пальиями (1), лоб без зморшок (1), рот від вуха до вуха (1), ніс із горбинкою (3), щоки з ямочками (3), талія з животом / пузом (4);

- студенти: голова нестандартної форми (2), волосся, зав'язане у хвіст (1), брови гарної форми (1), вуха середньої величини (54), ніс із горбинкою (32), шкіра з прищами (3), шкіра без дефектів (2) / з дефектами (2), щоки з ямочками (21), зуби з каріссом (14), плечі спортивної форми (2), руки середньої довжини (38), руки з довгими пальиями (7) / короткими пальиями (2), талія з пузом / животом (10), лоб зі зморшками (1), лоб із чуприною (1), рот від вуха до вуха (1), рот правильної форми (1);

- респонденти віком від 25 до 55 років: голова середньої величини (3), голова з діркою(1), обличчя з прищами (13), обличчя з вилииями (1), обличчя з ластовинням (1), щоки з рум'янцем (3), зуби з карієсом (3), ніс із горбинкою (21), шия середньої довжини (8), шкіра з прищами (15), плечі спортивної форми (1), руки з довгими пальиями (1), руки середньої довжсини (5), лоб зі зморшками (4) / без зморшок (3), рот із приємним запахом (1), волосся без лупи (3) / з лупою (2), брови без форми (1), талія з великим животом (8).

Очевидно, що представлені деталізовані описи для вираження переважно негативних рис людини частіше використовують студенти та респонденти віком від 25 до 55 років, ніж школярі. Помічено також, що в подібних описових конструкціях, фіксованих студентами та старшими за віком респондентами, застосовуються словосполучення середньої довжини, гарної форми, нестандартної форми, правильної форми, які узагальнюють образ і не дають чітких уявлень про об'єкт дослідження. 
Досить яскраво простежуються соціально-вікові відмінності мовної діяльності в застосуванні порівнянь для створення образу українця чи українки. Старша вікова група респондентів використовують значно менше порівнянь (зафіксовано 5), описуючи зовнішність людини, переважно для передачі ідеальних рис української дівчини: щоки як яблучко (1), шкіра - “кров з молоком” (1), постава, як у балерини (1). У студентському мовленні поряд із позитивною семантикою порівнянь знаходимо й порівняння іронічно-негативного характеру: очі голубі як небо (1), очі як волошки (1), брови густі, як щітки (1), ноги, як сірники (1), шкіра, як сметана (1), талія, як балія (1). Школярі застосовують теж різні емоційно забарвлені конотації: очі сині, як небо (1), щоки, як яблучко (1), щоки запливли (1), вуста, як маки (1), ніс, як картопля (8), шкіра, як сметана (2), плечі, як у плавців (1).

Досить поширеними в мовній діяльності молоді виявилися асоціаціїаналогії з частинами тіла тварин, а також ремінісцентні асоціації (ніс Буратіно) як засіб карикатури, шаржування небажаних для ідеалу рис. Школярі та студенти зафіксували подібні реакції, наприклад: щоки, як $у$ хом'ячка (20), вуха, як у Чебурашки (17), вуха, як у зайия (2) / у слона (4), ніс, як у Буратіно (2), шия, як у жирафи (3) / страуса (1), талія, як у корови (1), свинячі очі (1).

Застосування таких порівнянь молоддю пояснюється бажанням виділитися, яскраво, емоційно виразити свої думки. Стереотипність окремих згаданих вище асоціацій виявляється, на думку Д. І. Терехової у тому, що “при сприйнятті наша свідомість виділяє і фіксує найяскравіші ознаки в зовнішності людини. Люди, характеризуючи особу, роблять вибір не 3 нескінченої більшості її нормативних властивостей, а з малої кількості ознак; при цьому вибирають найвідміннішу, те, чим людину означила природа" [12, с. 46].

Помічено, що у представників усіх вікових груп одинично чи малочастотно фіксуються асоціації-персоналії. Об'єктом аналогії виступають переважно сучасники, зірки спорту та телебачення, а також політичний діяч минулої епохи - Брежнєв, наприклад:

- школярі: брови, як у Брежнєва (2);

- студенти: брови, як у Брежнєва (7), плечі, як у Кличка (1), талія, як у Р. Писанки (1);

- респонденти віком від 25 до 55 років: плечі, як у Клочкової (1).

Цікаво, що образ “брежнєвських" брів твердо закріпився в мовній свідомості не лише багатьох поколінь, а й навіть застосовується сучасними школярами.

Аналізуючи відповіді студентів у формі порівнянь, можемо констатувати тенденцію до етнокультурних змін у мовній свідомості сучасної молоді. Про це свідчать такі порівняння: вуса, як у козака (4), постава, як у козака (1). К. І. Мізін стверджує, що це є “ наслідком зміни 
державної ідеології - прищеплення молоді національних ідей, за допомогою яких молоді люди мають поціновувати своє етнокультурне коріння" [9, с. 74]. Дослідження автостереотипів українців за допомогою соціолінгвістичного експерименту дає можливість робити висновки про мовну толерантність сучасних комунікантів. Аналіз порівнянь, що характеризують небажані для ідеалу риси, свідчить про більший рівень мовної толерантності старшого покоління, ніж школярів та студентів. Специфіка мовного вираження в портретуванні українців молоддю виражається в застосуванні більш експресивних, нестандартних мовних одиниць, натомість представники старшого покоління застосовують усталені, експресивно нейтральні означення, евфемізми. У відповідях школярів знаходимо такі стилістично негативно марковані одиниці: дурна голова (1), тупа голова (2), тупе обличчя (11), запухле обличчя (1), риже волосся (18), жирні щоки (1), жирна талія (4), талія з пузом (4), ноги колесом (1); відповіді студентів: дурна голова (7), безтолкова голова (4), риже волосся (15), рижі брови (17), жирна талія (11), талія з пузом (5), ноги колесом (26), здоровенний рот (1). Старша вікова група демонструє емоційну нейтральність, описуючи соматизми: нерозумна голова (34), порожня голова (3) голова з діркою (1), руде волосся (25), руді брови (32), круглі щоки (2), велика талія (5), товста талія (27). Факт мовної толерантності великою мірою пояснюється тим, що старшу вікову групу представляють переважно освічені верстви населення Волинської області (вчителі, бібліотекарі, державні службовці), кому властива стереотипність мовної поведінки в оцінюванні рис українського хлопця та дівчини.

Якщо говорити про загальні особливості творення автостереотипів, то варто відзначити, що реакції респондентів залежать від семантики стимульного матеріалу, тому різні слова дають різну кількість варіантів відповідей. У всіх групах респондентів однаково мають велику семантичну валентність соматизми: обличчя, волосся, очі, щэоки, вуста, ніс, шкіра, руки, талія, ноги, які становлять ядро у створенні ідеальних образів. Значно меншою кількістю реакцій характеризуються слова-стимули зуби, вуха, шия, плечі, постава, зріст, очевидно, вони не є яскравими виразниками зовнішності українців.

Представники кожної вікової групи фіксують означення, сформовані на основі етнонімів, наприклад: школярі - грещький ніс (2); студенти греиький ніс (2), грузинський ніс (2); респонденти віком від 25 до 55 років - очі східного типу (1). Це демонструє, як на мовному рівні реалізується етноцентризм, через опозицію (своє ідеальне - чуже неідеальне) відбувається самоідентифікація особистості. Цим і пояснюються такі протиставлення, як світла - темна шкіра, круглі - вузькі очі. Надається перевага тим рисам зовнішності, які мовцям етнічно ближчі, що спостерігаються щодня. 
Аналіз результатів соціолінгвістичного експерименту дозволяє констатувати, що: 1) автостереотип у сприйнятті сучасних мовців $є$ досить повним, яскравим образом; 2) для створення мовного портрету реципієнти послуговуються різноманітними означеннями; 3) найтиповішими асоціаціями для опису соматизмів були означення з семантикою кольору, розміру та форми, тобто зовнішні ознаки. Загалом структура ідеальних та небажаних для ідеалу образів українців представлена прикметниковими означеннями, компонентами, що становлять іменник із прийменником, порівняннями (ремінісценсії, аналогії).

Соціально-віковий аспект портретування українців виражається здебільшого головним чином у виборі мовних засобів змалювання ідеальних та небажаних для ідеалу рис зовнішності. Школярам та студентам властиве використання порівнянь, аналогій, ремінісценсій, засобів шаржування та гіперболізації образу. Старшій віковій групі притаманна мовна толерантність, описи представників цієї групи характеризуються емоційною нейтральністю, використанням узусних епітетів та евфемізмів. Варто зауважити, що найчастотніші типові реакції засвідчують більше спільності, ніж відмінності у сприйнятті ідеальних образів українців різними соціальними групами. Проте помічені відмінності дозволяють нам говорити про специфіку мовного вираження автостереотипу різними соціальними групами. Малочастотні та індивідуальні відповіді респондентів яскравіше відображають соціальновікову специфіку мовного портретування.

\section{Література}

1. Богдан С. К. Стереотипи мовної поведінки сучасної волинської молоді: типологія звертань / С. К. Богдан // Науковий вісник ВДУ. Філологічні науки. 2000. - №6. - С. 36 - 40.

2. Голубовська I. О. Етнічні особливості мовних картин світу: монографія / І. О. Голубовська. - К. : Логос, 2004. - 284 с.

3. Горошко Е. И. Языковое сознание: гендерная парадигма : монография / Е. И. Горошко. - М.-Харьков : Издательский дом «ИНЖЭК», 2003. - 440 с.

4. Данилюк Н. Поетичне слово в українській народній пісні : монографія / Ніна Олексіївна Данилюк. - Луцьк : Волин. нац. ун-т ім. Лесі Українки, 2010. - 512 с.

5. Жайворонок В. В. Українська етнолінгвістика : нариси [навч. посіб. для студ. вищих навч. закл.] / В. В. Жайворонок . - К. : Довіра, 2007. - 262 с.

6. Залізняк Г. Мовна ситуація Києва: день сьогоднішній та прийдешній Г. Залізняк, Л. Масенко. - К.: Вид. дім “Академія”, 2001. - 95 с.

7. Засєкіна Л. В. Вступ до психолінгвістики : [навч. посібн.] / Л. В. Засєкіна, С. В. Засєкін. - Острог : Вид-во Нац. ун-ту “Острозька академія”, 2002. - 168 с.

8. Маслова В. А. Лингвокультурология : [учеб. пособие для студ. высш. учеб. заведений] / В. А. Маслова. - М. : Издательский центр «Академия», 2001. - 208 с.

9. Мізін К. І. Психолінгвістичний експеримент чи соціолінгвістичний моніторинг? Епістемологічні пошуки аксіологічної фразеології (на матеріалі компаративної фразеології) / К. І. Мізін // Мовознавство. - 2008. - №1 . - С. 67-79. 
10. Мусієнко В. П. Психолінгвістика : підручник / В. П. Мусієнко. - К.: Либідь, 1997. -95 c.

11. Ставицька Л. Арго, жаргон, сленг: Соціальна диференціація української мови / Леся Ставицька. - К. : Критика, 2005. - 464 с.

12. Терехова Д. І. Асоціативний портрет українця та росіянина / Д. І. Терехова // Мовознавство. - 1997. - №6. - С. 42 - 50.

Стаття надійшла до редакиії 27.10.2010 p. 